International Journal of Agriculture, Environment and Bioresearch

Vol. 4, No. 05; 2019

ISSN: $2456-8643$

\title{
HOUSEHOLDS MEAT AND FISH DEMAND IN PORT HARCOURT LOCAL GOVERNMENT AREA OF RIVERS STATE, NIGERIA
}

\author{
Dr. Thankgod Peter Ojimba* And Chioma Akoma \\ Department of Agriculture, Ignatius Ajuru University of Education Ndele Campus,P.M.B. 5047, Port Harcourt, \\ Rivers State, Nigeria \\ http://doi.org/10.35410/IJAEB.2019.4454
}

\begin{abstract}
This study focused on meat and fish demand among households in Port Harcourt Local Government Area (LGA) of Rivers State Nigeria, using linear approximate almost ideal demand systems (LA/AIDS) model. Data were collected using structured questionnaires and multi-stage sampling technique was employed to randomly sample 120 households. The results of LA/AIDS own price variables were significant at $1 \%$ and inelastic with beef coefficient $(-0.152)$, goat meat $(-0.476)$, chicken (0.295) and fish (-0.128) respectively. The results of household size and education variables were significant at $1 \%$ level while age was significant at $10 \%$. Elasticity results showed that the respondents were insensitive to price changes in beef (-0.0390), chicken $(-0.3629)$ and fish $(-0.3160)$ while they were sensitive to price changes in goat meat $(-2.7939)$. The cross-price elasticity estimates revealed chicken and fish were complementary products whereas beef and goat meat were substitutes. Chicken was a luxury good (2.782) by expenditure elasticity estimated, whereas beef (0.693) and fish (0.682) were necessary goods. Finally, the expenditure results revealed all meat and fish products surveyed were normal goods in the study area
\end{abstract}

Keywords: Meat, fish, demand elasticity, LA/AIDS model, Port Harcourt LGA, Rivers State Nigeria.

\section{INTRODUCTION}

World demand for meat has risen sharply since the last few decades (Dave, 2003). The key reasons for this increase in meat demand are increasing population, increasing income and improved technology of production. Meat demand in most African countries is still very low at a level of $25 \mathrm{gm}$ per day and demand is even lower especially in the southern part of Nigeria where production of animal protein has not been high enough to meet the demand of the rapidly growing population (Obi, 2003; Saumell, 2014, Premium Times, 2014). Because of this gap in demand there is high price of animal protein most especially beef, mutton and goat meat which had made an average Nigerian household to regard fish and poultry meat as a close substitute for food. This observation has led toincrease in per capita consumption of fish and poultry meat in recent years. Besides, the surge in fish demand in the country have also been associated with increase in aquaculture fish, contributing more than $200 \%$ of the total fish supply in the country (Ogundari and Akinbogun, 2010).

Fish is adjudged to be nutritionally superior to the other sources of animal protein containing most of the requisite amino acid particularly lysine, leusine, valine, methionine and 
tryptophan and hence fish is regarded as first class protein producer (Anyanwu, 2014). This implies that fish posses the requisite potential of bridging the gap in the inadequate protein intake of most Nigerians when harnessed properly.

Meat and fish being important sources of protein have played significant roles in the pattern of food consumption. In Rivers State, meat and fish are known widely as very important part of the diet because of their high nutritive value and significance in improving human health. Fish and meat which contribute $36.6 \mathrm{gm}$ and $46.7 \mathrm{gm}$ per day net protein utilization in Nigerian homes are still below the recommended requirements by the World Health Organization (Amao et al., 2006). This short fall is not because of non-availability of the resources but due to non maximization and sustainable utilization of available aquatic resources. At household level, the demand for fish and meat may depend on the availability of income, size and prices of fish, beef and other meat products.

It is for this reason that this study decided to ascertain the variables influencing the demand for meat and fish, and the preferential characteristics of fish and meat demand among households in Port Harcourt Local Government Area (LGA) using Linear Approximate Almost Ideal Demand Systems (LA/AIDS) model for analysis of data collected from cross sectional survey.

There are literature on fish and meat demand in different parts of the world and Nigeria. These include Mdafi and Borsen (1993), Jamison and Leslie (2001), Tey et al. (2008a: 2008b), Wenneberg et al. (2012). In Nigeria the studies include Ohajianya (2005), Osho and Nazemzadeh (2005), Adetunji and Rauf (2012), Yusuf (2012), Emakero and Dibiah (2014), AborisadeadCarpio (2017) and others. The significance of this study lies in the fact that many studies had treated similar topics, but none had treated it in this areaof study and in details. Anyanwu et al. (2012) studied a similar topic concentrating mainly on factors affecting beef and fish consumption but used multiple regression analysis. Ekine et al. (2012) also worked on meat and fish demand but covered a different LGA (Obio/Akpor LGA) of Rivers State, Nigeria using multiple regression methods. Ojimba and Odiegba(2017) studied the micro level of beef demand in selected parts of Rivers State using multiple regression models. However, this study estimated the demand for meat and fish among households in Port Harcourt LGA in Rivers State, Nigeria using a Linear Approximate Almost Ideal Demand Systems (LA/AIDS) model estimating the elasticity i.e. own price, cross price and expenditure elasticity. The main difference between single equation model and LA/AIDS is that the latter employs budget share as dependence variable, while the single equation makes use of quantity consumed as dependent variable (Adetunji and Rauf, 2012). The beneficiaries of this study are government officials, policy makers, agricultural economics, nutrition and food specialists, researchers and students at different levels of study.

The main objective of this study is to determine the level of meat and fish demand among households in Port Harcourt LGA in Rivers State Nigeria using Linear Approximate Almost Ideal Demand Systems (LA/AIDS) model. The specific objectives are to:

(i) Determine the factors affecting the demand for meat and fish among households in Port Harcourt LGA in Rivers State, Nigeria.

(ii) Estimate the elasticity of demand for meat and fish in households in Port Harcourt LGA of Rivers State, Nigeria. 
(iii)Make policy recommendations as it relates to meat and fish demand in Port Harcourt LGA.

\section{MATERIALS AND METHODS}

\subsection{The area of study}

This study was conducted in Port Harcourt Local Government Area (LGA) of Rivers State, Nigeria in 2017. Rivers State lies between longitude $6^{0} 50^{\mathrm{E}}$ and $7^{0} 30^{\mathrm{E}}$ and latitudes $4^{0} 30^{\mathrm{N}}$ and $5^{0} 30^{\mathrm{N}}$ north of the Equator. The state occupies the southern tip of the country, Nigeria. It is made up of 23 local government areas (LGAs) of which Port Harcourt LGA is one and the administrative headquarters of the state. Port Harcourt is divided into two LGAs namely Port Harcourt LGA and Obio/Akpor LGA. The choice of this study area was due to the peculiar nature of the inhabitants comprising of people with a fair representation of different tribes in Nigeria varying in categories of income (low, medium and high) and diverse occupations.

\subsection{Population of the study}

The population of this study is all households and markets in Port Harcourt LGA representing different ethnic nationals and major tribes of Nigeria living in the city, who consume and demand for meat and fish.

\subsection{Data collection.}

Data for this study was obtained from primary and secondary sources. The primary data were obtained from questionnaires, interviews and discussionswith the respondents on demand for meat and fish. The survey was cross-sectional because of the short term nature of the project. Questionnaires were formulated, printed and distributed among fish and meat consumers, sellers and buyers. The questionnaire contained such information as factors affecting the demand for meat and fish among households in the study area including age, education, household size, income, own prices, prices of other meat and fish products, and expenditures on various commodities.

\subsection{Sample and Sampling Techniques}

A multi stage sampling technique was employed. The first stage involved choosing three markets in Port Harcourt LGA out of the numerous markets available. The three markets selected purposely were Town Market, Mile One Market and Mile Three Market respectively. These three markets were selected because of their popularity and proximity to the researchers. The second stage of sampling involved obtaining list of meat and fish sellers from the market authorities in the different markets selected, who were then randomly selected. The third stage of sampling procedure included drawing a sample of 20 sellers of meat and fish, and 20 household heads who demanded and purchased or consumed meat and fish during the period of survey in the same market. This gave a total of 120 respondents interviewed and served questionnaires by the researchers of which all questionnaire were retrieved and used for analysis.

\subsection{Data Analysis}

The data obtained during the survey were analyzed using Linear Approximate Almost Ideal Demand Systems (LA/AIDS) model as in objectives (1) and (2). 


\subsection{Estimating a linear approximate almost ideal demand system model.}

The Almost Ideal Demand System (AIDS) model of Deaton and Muellbauer (1980a) enjoyed great deal of popularity in the area of applied demand analysis. Beginning from specific cost function, the almost ideal demand system (AIDS) model had given the share equation in an n-good system as used by different authors (Green and Alston, 1990; Baharumshah and Mohamed, 1993; SAS Institute Inc., 1999; Osho and Nazemzadeh, 2005; Tash et al., 2012; Motallebi and Pendel, 2013; Basarir, 2013);

$\mathrm{w}_{\mathrm{i}}=\alpha_{\mathrm{i}}+\sum \gamma_{\mathrm{ij}} \ln \mathrm{p}_{\mathrm{j}}+\beta_{\mathrm{i}} \ln (\mathrm{X} / \mathrm{P})$

Eq. 1

where,

$$
j=1
$$

$\mathrm{w}_{\mathrm{i}}=$ the budget share associated with the ith good;

$\alpha_{\mathrm{i}}=$ the constant coefficient in the ith share equation;

$\gamma_{\mathrm{ij}}=$ the slope $\mathrm{n}_{\mathrm{n}}$ oefficient associated with the jth good in the ith share equation;

$\mathrm{p}=$ the price of the jth good (i.e. meat and fish).The meat and fish products include beef, goat meat, chicken and fish.

$\beta_{i}=$ coefficients of the ith variables $\left(\beta_{0}-\beta_{7}\right)$ which includes the coefficient of meat and fish products and demographic variables.

$\mathrm{X}=$ the expenditure on the system of goods (meat and fish) given by:

$X=\quad \sum_{n} p_{i} q_{i}$

Eq. 2

where,

$\mathrm{q}_{\mathrm{i}}=$ the quarititites demanded for the ith good (ie. meat and fish products)

$\mathrm{p}_{\mathrm{i}}=$ the price demanded for the ithgood (where $\mathrm{i} \neq \mathrm{j}$, cross price and $\mathrm{i}=\mathrm{j}$, own price)

$\mathrm{P}=$ the price index defined by:

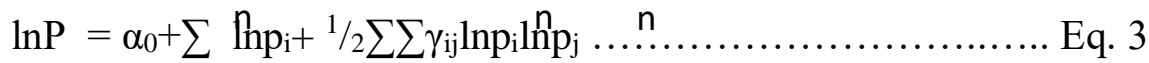

in the non - linear AIDS model.

Deaton and Muellbauer $(\overline{1} 1980 \mathrm{~b})=1$ also suggested a linear approximation of the non-linear AIDS model i.e. Linear Approximate Almost Ideal Demand Systems (LA/AIDS) model by specifying a linear price index given by:

$\ln \mathrm{P}=\sum \mathrm{w}_{\mathrm{i}} \ln \mathrm{p}_{\mathrm{i}}$

Eq. 4

that gives rise to the Linear Approximate AIDS (LA/AIDS) model. The LA/AIDS model is a more frei $\mathrm{i}=1 \mathrm{1}$ ently estimated model than the non linear AIDS model in recent times (Ezedinma et al. 2006; Tey et al., 2008b; Tey et al., 2010; Yusuf, 2012; Emakaro and Dibia, 2014; Aborisade and Carpio, 2017).

Considerably the following restrictions on the parameters in the non linear AIDS model can be applied as follows:

$\sum \alpha_{\mathrm{i}}=1 ; \sum \beta_{\mathrm{i}}=0 ; \sum \gamma_{\mathrm{ij}}=0$

The $h_{p=1}=1$ geneity is satisfied if and only if, for alli

$\sum \gamma_{\mathrm{ij}}=\mathrm{n}$ Eq. 6

and the symmetry is satisfied also, if

$\gamma_{\mathrm{ij}}=\gamma_{\mathrm{ji}}^{\mathrm{j}}=1$ 
The use of the stone price index enables the inclusion of demographic characteristics (Sadoulet and de Janvry, 1995; Ezedinma, 2006; Adetunji and Rauf, 2012).For consumable goods, the translation approach is more useful for modeling of demographic effects (Alessie and Kapteyn, 1991; Blancitorti and Green 1993). The linear approximation of the AIDS model is improved by the stone price index as prices of meat and fish products were involved.

In equation (1) above, the intercept term $\left(\alpha_{i}\right)$ is further specified as follows:

$\alpha_{\mathrm{i}}=\alpha_{0}+\sum \alpha_{\mathrm{ij}} \mathrm{D}_{\mathrm{j}}$

Eq. 8

where, $\alpha_{0}=$ constant variables (coefficient).

$\mathrm{D}_{\mathrm{j}}=$ the $\mathrm{jth}$ demographic variable.

The extended model (LA/AIDS) which includes the demographic variables age, education and household size and the error term $\left(V_{\mathrm{i}}\right)$ is identified as follows:

$\mathrm{w}_{\mathrm{i}}=\alpha_{0}+\sum \alpha_{\mathrm{ij}} \mathrm{D}_{\mathrm{j}}+\sum \gamma_{\mathrm{ij}} \ln \left(\mathrm{p}_{\mathrm{i}}\right)+\beta_{\mathrm{i}} \ln (\mathrm{X} / \mathrm{P})+V_{\mathrm{i}}$

As a system of equations, the budget share equations were estimated simultaneously using the Statistical Analysis System (SAS) package.

\subsection{The estimation of price and expenditure elasticities in LA/AIDS}

The LA/AIDS model derived the price and expenditure elasticities from the parameter estimates (Green and Alston, 1990; Ezedinma et al., 2006; Adetunji and Rauf, 2010) as follows:

(i) Own - price elasticity: $\sum_{\mathrm{ii}}=-1+\left(\gamma_{\mathrm{ii}} / \mathrm{w}_{\mathrm{i}}\right)-\beta_{\mathrm{i}}$ .Eq. 10 where,

$\sum \mathrm{ii}=$ own price elasticity

$(\mathrm{i}=\mathrm{j})$

$\gamma_{\mathrm{ii}}=$ expenditure coefficient of the ith commodity

$\mathrm{W}_{\mathrm{i}}=$ geometric mean of the budget share (dependent variables).

$\beta_{i}=$ coefficient of household expenditure variables.

(ii) Cross - price elasticity: $\sum=\left(\gamma_{\mathrm{ij}} / \mathrm{w}_{\mathrm{i}}\right)-\beta_{\mathrm{i}}\left(\mathrm{w}_{\mathrm{j}} / \mathrm{w}_{\mathrm{i}}\right)$, fori not equal to $\mathrm{j}(\mathrm{i} \neq \mathrm{j}) \ldots \ldots \ldots$. Eq. 11 where, $\sum \mathrm{ij}=$ cross price elasticity

$\gamma_{\mathrm{ij}}=$ expenditure coefficient of ijth commodity.

$\mathrm{W}_{\mathrm{i}}=$ geometric mean of the budget share (dependent variable).

$\mathrm{W}_{\mathrm{j}}=$ geometric mean of price of each of the meat types

$\beta_{\mathrm{i}}=$ coefficient of household expenditure variables.

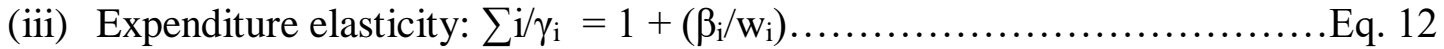

$\sum \mathrm{i} / \gamma=$ expenditure elasticity

$\beta_{\mathrm{i}}=$ coefficient of household expenditure variables.

$\mathrm{W}_{\mathrm{i}}=$ geometric mean of the budget share (dependent variables.)

\section{A priori expectations}

The a priori expectations are as follows:

Price: If the price of a commodity increases, the quantity demanded of those commodity decreases thereby causing a substitution effect. The substitution effect measures how much the higher prices encourages consumers to use other goods, assuming their income remains the same.

Age: The age of the consumer affects the demand for red meat (beef and goat meat) and fish products. The older the head of the household, the less likely they will be purchasing beef and goat meat (Wenneberg et al., 2012). 
Household size: As household size increases, the expenditure on meat and fish products tends to rise but this depends largely on the income disposition of the household head. The fact that there is an increase in the household size alone does not or may not cause a significant increase in demand for meat and fish products.

Education: The more educated the consumer is, the less likely he will be purchasing more beef and other red meat. An educated consumer is likely to be rational in decision making for meat and fish products and hence responds to the protein requirement of the household.

\section{RESULTS AND DISCUSSION}

To determine the key factors influencing the demand for meat and fish products among households in Port Harcourt Local Government Area (LGA) of Rivers State, Nigeria, the Linear Approximate Almost Ideal Demand Systems (LA/AIDS) model was used. The results of the LA/AIDS model are presented on Table 1 analyzing factors such as beef, goat meat, chicken, fish, age, household size and education while Table 2 gave the results of price and expenditure elasticity of meat and fish.

\subsection{Linear approximate almost ideal demand system (LA/AIDS) model}

Table 1 shows the coefficients of the variables which were interpreted directly as increase or decrease in the proportion of meat and fish products demanded and the budget share allocated to each of the meat and fish products. All the own price variables (beef, goat meat, chicken and fish) were significant at $1 \%$ level and possessed the expected negative signs for a demand curve, suggesting that an increase in price led to a decrease in the quantity of meat and fish products demanded in Port Harcourt LGA in Rivers State, Nigeria as earlier stated in the a priori expectations. The results in Table 1 also showed that beef had a coefficient of -0.152 which was significant at $1 \%$, showing an inelastic decrease in demand, meaning that $10 \%$ increase in the price of beef led to a $1.52 \%$ reduction in the quantities of beef demanded. However, households in Port Harcourt LGA compensated for the inelastic reduction by increasing their demand for goat meat (though inelastically) by 0.09 (not statistically significant), chicken by $0.93 \%$ (which was statistically significant at $1 \%$ ) and reduction on fish by $0.12 \%$ (not significant) respectively.

Goat meat had a coefficient of -0.476 (significant at $1 \%$ ), also showing an inelastic decrease in quantity demanded, meaning a $10 \%$ increase in the price of goat meat necessitate an inelastic reduction in quantity demanded by $4.76 \%$. This is to say that households in Port Harcourt LGA compensated for this reduction by increasing (though inelastically) their household demand for beef by $2.65 \%$ (significant at $1 \%$ ), chicken by $0.6 \%$ (significant at $10 \%$ ) and fish demand by $0.82 \%$ (also significant at $10 \%$ ) respectively. With respect to chicken, it had a coefficient of -0.295 (significant at $1 \%$ level) which was also an inelastic decrease in quantity demanded.

Table 1: Results of estimates of linear approximate almost ideal demand systems (LA/AIDS) model

\begin{tabular}{|l|l|l|l|l|l|}
\hline Variables & Parameters & Beef & Goat Meat & Chicken & Fish \\
& & $\gamma_{1}$ & $\gamma_{2}$ & $\gamma_{3}$ & $\gamma_{4}$ \\
\hline
\end{tabular}


Vol. 4, No. 05; 2019

ISSN: $2456-8643$

\begin{tabular}{|c|c|c|c|c|c|}
\hline Beef & $\beta_{1}$ & $\begin{array}{l}-0.152 * * * \\
(-4.650)\end{array}$ & $\begin{array}{l}0.009 \\
(0.550)\end{array}$ & $\begin{array}{l}0.093 * * * \\
(4.470)\end{array}$ & $\begin{array}{l}-0.012 \\
(-0.42)\end{array}$ \\
\hline Goat Meat & $\beta_{2}$ & $\begin{array}{l}0.265^{* * *} \\
(4.320)\end{array}$ & $\begin{array}{l}-0.476 * * * \\
(-14.850)\end{array}$ & $\begin{array}{l}0.060 * \\
(1.631)\end{array}$ & $\begin{array}{l}0.082 * \\
(1.565)\end{array}$ \\
\hline Chicken & $\beta_{3}$ & $\begin{array}{l}0.118^{* * *} \\
(3.540)\end{array}$ & $\begin{array}{l}0.025 \\
(1.410)\end{array}$ & $\begin{array}{l}-0.295 * * * \\
(-14.772)\end{array}$ & $\begin{array}{l}0.120^{* * *} \\
(4.181)\end{array}$ \\
\hline Fish & $\beta_{4}$ & $\begin{array}{l}0.180 \\
(0.860)\end{array}$ & $\begin{array}{l}0.006 \\
(0.550)\end{array}$ & $\begin{array}{l}-0.066 * * * \\
(-5.270)\end{array}$ & $\begin{array}{l}-0.128 * * * \\
(-7.170)\end{array}$ \\
\hline Age & $\beta_{5}$ & $\begin{array}{l}0.049 * \\
(1.860)\end{array}$ & $\begin{array}{l}0.007 \\
(1.430)\end{array}$ & $\begin{array}{l}0.315^{*} \\
(1.714)\end{array}$ & $\begin{array}{l}0.136 \\
(0.173)\end{array}$ \\
\hline $\begin{array}{l}\text { Household } \\
\text { size }\end{array}$ & $\beta_{6}$ & $\begin{array}{l}0.509 * * * \\
(3.450)\end{array}$ & $\begin{array}{l}0.661 * * * \\
(4.083)\end{array}$ & $\begin{array}{l}0.139 * * * \\
(3.371)\end{array}$ & $\begin{array}{l}0.907 * * * \\
(5.479)\end{array}$ \\
\hline Education & $\beta_{7}$ & $\begin{array}{l}-0.227 * * * \\
(-3.450)\end{array}$ & $\begin{array}{l}-0.141 \\
(-1.952)\end{array}$ & $\begin{array}{l}0.385^{* * *} \\
(5.210)\end{array}$ & $\begin{array}{l}2.704 \\
(1.006)\end{array}$ \\
\hline Intercept & $\beta_{0}$ & $\begin{array}{l}-0.065 \\
(-0.340\end{array}$ & $\begin{array}{l}0.970 * * * \\
(9.751)\end{array}$ & $\begin{array}{l}-0.036 \\
(-0.311)\end{array}$ & $\begin{array}{l}-0.142 \\
(-0.860)\end{array}$ \\
\hline
\end{tabular}

Source: Estimated from Field Survey, 2017 data. Figures in parenthesis are t- values. *** $=$ significant at $1 \% ; * *=$ significant at $5 \% ; *=$ significant at $10 \%$.

Therefore, a $10 \%$ increase in price of chicken brought about a $2.95 \%$ reduction in the quantity demanded by the households in the study area. This inelastic decrease in quantity demanded was compensated for, by increasing the demand for beef by $1.18 \%$ (significant at $1 \%$ ), increase in demand for fish by $1.20 \%$ (also significant at $1 \%$ ) and goat meat by $0.25 \%$ (though not statistically significant).

For fish demand, the coefficient was -0.128 , significant at $1 \%$, indicating an inelastic decrease in demand, meaning a $10 \%$ increase in price of fish, certainly led to a $1.28 \%$ decrease in quantity of fish demanded by households in Port Harcourt LGA of Rivers State, Nigeria. This inelastic decline in the quantity of fish demanded was taken care of by an increase in the demand for beef by $1.80 \%$ and $0.06 \%$ in goat meat bought (statistically not significant figures) but a decline in the purchase of chicken meat by $0.66 \%$ (significant at $1 \%$ level). 
This study found out that Port Harcourt LGA households reacted differently to small changes on the market prices of meat and fish products respectively. Chicken meat had a greater number of other meat products (beef and goat meat) that were significant as substitutes and fish as a complement in response to price changes while most of the surveyed households in Port Harcourt LGA could easily switch their demand to other meat products, considering the insignificant changes in the market price of goat meat. These results are similar to the results of Osho and Nazemzadeh, (2005), Ezedinma et al. (2006), Tey et al.(2008a, 2008b, 2010), Adetunji and Rauf, (2012), Onyeneke and Nwaiwu, (2012), Aborisade and Carpio, (2017).

Further, on Table 1, the results of the effects of the demographic variables such as age, household size and education on the demand for meat and fish products in the LGA are shown. The results on the table showed that the intra-household demand pattern of the respondents for beef and chicken which were significant at $10 \%$ with respect to age. This means that as the household head became older by $10 \%$ in age, the demand for beef increased (though inelastically) by $0.49 \%$ (significant at $10 \%$ ), demand for chicken increase by $3.15 \%$ (significantly at $10 \%$ level) and the demand for fish also increased by $1.36 \%$. This showed that more of the older respondents demanded for chicken and fish more than the red meat (beef and goat meat).

With respect to household size, the household heads demand for beef, goat meat, chicken and fish were all significant at $1 \%$ level. So, for a $10 \%$ increase in household size, the household heads demand for beef increase by $5.09 \%$, goat meat by $6.61 \%$, chicken by $1.39 \%$ and fish by 9.07\%.This means that the larger the household size the more quantity of fish, goat meat and beef demanded, with lesser quantity of chicken supplemented occasionally. However, this is subject to availability of income and/or income status of the household head. These results on household's size in this study are similar to the results of Ezedinma et al. (2006).

The education variable in Table 1 had coefficients of -0.227 for beef and chicken (0.385), both statistically significant at $1 \%$, goat meat $(-0.141)$, significant at $10 \%$, and fish (2.704), not statistically significant, despite its high elastic demand coefficient. These results revealed that for a $10 \%$ increase in the educational level of the household head, demand for beef will decrease by $2.27 \%$, demand for goat meat also will decrease by $1.41 \%$, while the demand for chicken will increase by $3.85 \%$ and the demand for fish will increase very elastically by $27.04 \%$. Therefore, the educated household heads in Port Harcourt LGA preferred the consumption of fish to chicken, which in turn is more preferred to the red meat (beef and goat meat) respectively.

In summary, the meat and fish variables used in the LA/AIDS model revealed that they were all significant at $1 \%$ level, indicating their importance. This study found out that a $10 \%$ increase in price of beef led to $1.52 \%$ reduction in itsquantity demanded. A $10 \%$ increase in the price of goat meat led to a $4.76 \%$ reduction in its quantity demanded, a $10 \%$ increase in the price of chicken led to a $2.95 \%$ reduction in quantity of chicken demanded while a $10 \%$ increase in fish left to a $1.28 \%$ decrease in quantity of fish demanded by the households in Port Harcourt LGA of Rivers State, Nigeria. This study also found out that household size, education and age were significant variables at $1 \%$ and $10 \%$ levels respectively, affecting the demand for meat and fish in the study area.

\subsection{Elasticity of demand for meat and fish products.}

The estimates of the elasticity of demand for meat and fish in Port Harcourt LGA using LA/AIDS are shown on Table 2. The table shows the own-price, cross-price and expenditure 
elasticities as estimated. The diagonal values represent the own-price elasticities. The negative values on the own - price elasticity coefficients of -0.0390 for beef, -2.7939 for goat meat, 0.3629 for chicken and -0.3160 for fish were consistent with the a priori expectations and in accordance with economic theory. The value of the coefficients showed that beef $(-0.0390)$ chicken (-0.3629) and fish (-0.3160) were price inelastic, while goat meat was price elastic (2.7939). These results confirmed that Port Harcourt LGA households were insensitive to price changes to beef, chicken and fish demand, while they were sensitive to price changesin goat meat.

Table 2. Expenditure and price elastically of meat and fish demand in Port Harcourt LGA.

\begin{tabular}{|l|l|l|l|l|}
\hline $\begin{array}{l}\text { Meat Product } \\
(\text { Parameter })\end{array}$ & Beef & $\begin{array}{l}\text { Goat meat } \\
\gamma_{1}\end{array}$ & $\begin{array}{l}\text { Chicken } \\
\gamma_{3}\end{array}$ & $\begin{array}{l}\text { Fish } \\
\gamma_{4}\end{array}$ \\
\hline Beef $\left(\beta_{1}\right)$ & $\mathbf{- 0 . 0 3 9 0 * * *}$ & $0.5166^{* * *}$ & $-0.0544^{* * *}$ & 0.8430 \\
& $\mathbf{( - 7 . 1 3 6 0 )}$ & $(3.1236)$ & $(-2.0102)$ & $(0.3481)$ \\
\hline Goat meat $\left(\beta_{2}\right)$ & $0.8926^{* * *}$ & $\mathbf{- 2 . 7 9 3 9 * * *}$ & $1.3452^{* * *}$ & $0.2573 * * *$ \\
& $(4.3462)$ & $\mathbf{( - 6 . 2 7 3 3 )}$ & $(3.8311)$ & $(2.671)$ \\
\hline Chicken $\left(\beta_{3}\right)$ & $0.4329 * * *$ & $1.8639 * * *$ & $\mathbf{- 0 . 3 6 2 9 * *}$ & $0.9063^{* * *}$ \\
& $(2.7612)$ & $(4.3718)$ & $\mathbf{( - 2 . 8 9 4 2 )}$ & $(5.474)$ \\
\hline Fish $\left(\beta_{4}\right)$ & $-0.5052^{* * * *}$ & -0.0201 & 0.4020 & $\mathbf{- 0 . 3 1 6 0 * * *}$ \\
& $(-6.2162)$ & $(-0.003)$ & $(0.2301)$ & $\mathbf{( - 7 . 3 0 8 2 )}$ \\
\hline $\begin{array}{l}\text { Expenditure } \\
\text { Elasticity }\end{array}$ & 0.693 & 1.014 & 2.782 & 0.682 \\
\hline
\end{tabular}

Source: Elasticity estimates from Field Survey, 2017 data. $* * *=1 \%$ level of significance; $* *=$ $5 \%$ level of significance; figures in parenthesis are t- values.

The cross-price elasticity estimates indicated that beef in relation to goat meat had a coefficient of 0.5166 and fish $(0.8430)$ were substitutes, while beef complemented with chicken $(-0.0544)$ meaning the respondents consumed these items together. Goat meat in relation to chicken was a substitute and the value was elastic (1.3452), it was also a substitute with beef (0.8926) and fish (0.2573), which were all significant at $1 \%$. Chicken in relation to beef was a complement (-0.4329), while it served as a substitute to goat meat which had an elastic coefficient (1.8639) and fish had the coefficient of 0.9063 which was significant at $1 \%$ level (almost elastic value), meaning the households were sensitive to their prices changes. Fish served as a complement to beef $(-0.5052)$ and was significant at $1 \%$ level, and also served as a 
complement to goat meat (-0.0201), which is normal observation especially in its dried form. However, fish was a substitute to chicken (0.4020).

Expenditure elasticities for the Port Harcourt LGA respondents were all positive. Some expenditure values were greater than one (elastic) especially the expenditure value for chicken (2.782) and goat meat (1.014). This means that the magnitude of own-price elasticity and expenditure elasticity on chicken and goat meat increases as income increases in the households, i.e. more chicken and goat meat will be bought by the households in the study area as their income increases. The expenditure elasticities on beef (0.693) and fish (0.682) were inelastic, i.e. expenditure on beef and fish will remain almost the same whether household income increases or nor. All meat and fish products studied were normal goods based on the positive coefficients obtained at the expenditure elasticities level. Beef and fish were necessary goods because of their inelastic values. They are also important based on their frequent demand by households as the dominant and traditional sources of protein in Port Harcourt LGA of Rivers State, Nigeria.

For every $10 \%$ increase in income of the households, expenditure on chicken increased by $27.82 \%$ (elastic increase) and $10.14 \%$ on goat meat (which is slightly above the unitary demand).Chicken and goat meat were classified as luxury goods in this study because of their elastic coefficients of 2.782 and 1.014 respectively. However, goat meat expenditure elasticity which was 1.014 showed that as income increases respondents demand for goat meat will remain almost at the same level in the LGA.

The results of this elasticity study are in agreement with Osho and Nazemzabeh, (2005), Ezedinma et al. (2006), Adetunji and Rauf (2012),Aborisade and Carpio (2017), and Ojimba and Odiegba (2017) results of own-price, cross-price and incomeelasticities. Osho and Nazemzabeh (2005) results showed that the expenditure elasticity of chicken was greater than one, implying that it was a luxury good. Ezedinma et al., (2006) results indicated that a rise in the price of beef led to the inelastic increase in demand for mutton/goat meat by $2.6 \%$ and fish $(2.5 \%)$ respectively. Adetunji and Rauf (2012) own-price elasticity results also showed that coefficients of beef (-0.827), chevon(goat meat) -0.527 and chicken (-0.721) were all inelastic. Ojimba and Odiegba (2017) results showed that the income elasticity forbeef was 0.2537 , indicating that beef was income inelastic, and had the character of a necessity and normal good. The results of Aborisade and Carpio(2017) showed that coefficient of own-price elasticity for goat meat (2.4899) was elastic and the expenditure elasticity for chicken was 2.0206 (also elastic).

In summary, in own-price variable for demand for beef, chicken and fish, the households were insensitive to the price changes, while they were very sensitive to the price changes in goat meat. The cross-price elasticity estimates indicated that goat meat and beef were strong substitutes, while chicken and fish were complements to thedemand of the households. The expenditure elasticities showed that all meat and fish products studied were normal goods. However, chicken was luxury good, while beef and fish were necessary goods in Port Harcourt LGA of Rivers State, Nigeria.

\section{CONCLUSION AND RECOMMENDATIONS}

\subsection{Conclusion}


The results of this survey analyzed using Linear Approximate Almost Ideal Demand Systems (LA/AIDS) model found out that most households in Port Harcourt LGA in Rivers State, Nigeria reacted differently to little changes in market prices of meat and fish products. Firstly, the survey found that chicken meat had a larger number of substitutes which included beef and goat meat and fish as a complement, meaning that most of the households surveyed easily switched their demand for meat and fish products because of the inelastic price changes.

Secondly, using the demographic variables in the LA/AIDS model revealed that more of the older respondents interviewed during the survey demanded for chicken and fish more than the red meats (beef and goat meat).The study also observed that larger households demanded more of fish, followed by goat meat and beef with lesser demand for quantity of chicken which served as supplement. The results further revealed that educated household heads preferred the consumption of fish to chicken which in turn was preferred to the consumption of red meat ( beef and goat meat) respectively.

Thirdly, the results of the own-price elasticities of the survey showed that respondents interviewed were insensitive to price changes to beef, chicken, and fish while they were sensitive to price changes in goat meat. The cross-price elasticity estimated results showed that chicken and fish were complementary products to the households in Port Harcourt LGA whereas beef and goat meat were strong substitute commodities.

Finally, the expenditure elasticity estimated for all meat and fish products showed that they were normal goods. However, chicken was a luxury good, whereas beef and fish were found to be necessary goods in the LGA.

\section{RECOMMENDATION}

This study, based on the findings of the survey, therefore recommends that:

(i) The various arms of government (including Port Harcourt Local Government Area) should assist livestock and fish farmers in the area to increase their production capacity both in quantity and quality of fish, goat, poultry, cattle and other types of livestock. This if adhered to will help reduce the fluctuation of price of livestock products and also increase the quantity and quality available. The required assistance will be in the form of loans and credits to farmers generally in the production of feeds and subsidy in the production and formulation of livestock vaccines, drugs and other equipment necessary for effective household production.

(ii) It is also being recommended that the government should expedite action on the payment of the new minimum wage to Nigeria workers as this will increase the purchasing power of many consumers of meat and fish products in Port Harcourt LGA and the country in general.

\section{ACKNOWLEDGEMENT}

We hereby acknowledge the efforts of staff and students of Department of Agriculture of the Ignatius Ajuru University of Education and the Management of the University on their assistance given to us to complete this project and the Rivers State Government for payment of salary which had enabled us to publish this article. We say thank you. We also appreciate all others whose efforts had made it possible for the field survey, result analysis and production of this report to have taken place. 


\section{REFERENCES}

Aborisade, O. and Carpio, C.E. (2017).Household demand for meat in Nigeria. Paper presented at the Southern Agricultural Economics Association's 2017 Annual Meeting, Mobile, Alabama, USA, 252839, February $4^{\text {th }}-7^{\text {th }}, 2017$.

Adetunji, M.O. and Rauf, M.O. (2012). Analysis of household demand for meat in Southwest, Nigeria. Global Journal of Science Frontier Research, 12 (1): 15 - 21.

Alessie, R. and Kapteyn, A. (1991). Habit formation, interdependent preferences and demographic effects in the almost ideal demand system. The Economic Journal, 101: 404-419.

Amao, J.O., Oluwataye, I.B. and Osuntope, F.K. (2006). Economics of fish demand in Lagos State, Nigeria. Journal of Human Ecology, 19 (1): 25 - 30.

Anyanwu, S.O., Manilla, H.A. and Ibekwe, U.C. (2012). Econometric analysis of demand for beef and fish in Rivers State, Nigeria. Journal of Vocational Education and Technology, 9 (2): $137-145$.

Anyanwu, S.O. (2014). Quantitative analysis of fish consumption in Rivers State, Nigeria. American Journal of Experimental Agriculture, 4 (4): 469 - 475.

Baharumshah, A.Z. and Mohamed, Z. (1993). Demand for meat in Malaysia: An Application of the almost ideal demand system analysis. Pertanika Journal of Social Science and Humanities, 1 (1): 91 - 99.

Basarir, A. (2013). An almost ideal demand system analysis of meat demand in UAE. Bulgarian Journal of Agricultural Science, 19 (1): 32 - 39.

Blanciforti, L. and Green, R. (1983). An almost ideal demand system incorporating habits: An analysis of expenditure of food and aggregate commodity group. The Review of Economics and Statistics, 65(3): 511 - 515. DOI:10.2307/1924200.

Dave H. (2003). Perspective on global markets for poultry products.Mineapolis.Mn 55328, U.S.A.

Deaton, A and Muellbauer, J. (1980a).Economics and consumer behavior. Cambridge, England. Cambridge University Press.

Deaton, A. and Muellbauer, J. (1980b). An almost ideal demand system.American Economic Review70: 312 - 336. 
Ekine, D.I., Albert, C.O. and Peregba, T.A. (2012). Expenditure pattern for beet consumption in selected households in southern Nigeria. Developing Countries Studies, 2 (7): 1-5.

Emakaro, C.O. and Dibia, O. (2014). Demand analysis for chicken meat, beef and fish among urban households in Edo and Delta States, Nigeria. Journal of Applied and Natural Sciences, 6 (1): $239-245$.

Ezedinma, C., Kormawa, P. and Chianu, J. (2006). Urban household demand for fish and meat products in Nigeria: An almost ideal demand system analysis.Paper prepared for presentation at the Farm Management Association of Nigerian Conference, Jos, Nigeria, Sept. $18^{\text {th }}-21^{\text {st }}, 2006,15-20$.

Green, R. and Alston, J.M. (1990).Elasticities in AIDS models. American Journal of Agricultural Economics, 72 (2): 442 - 445.

Jamison, D.T. and Leslie, J. (2001).Evidence from China and Comparison. Food and Nutrition Bulletin, 24 (2) : 145 - 154.

Mdarfi, A. and Borsen, B.W. (1993). Demand for red meat, poultry and fish in Morocco: An almost ideal demand system. Agricultural System, 9: 155 - 163.

Motallebi, M. and Pendell, D.L. (2013). Estimating an almost ideal demand system model for meats in Iran. Selected Paper prepared for presentation at the Agricultural Applied Economics Association's 2013 AAEA \& CAES Joint Annual Meeting, Washington, D.C. August $4^{\text {th }}-6^{\text {th }}, 2013,1-25$.

Obi, C.I. (2003). Game production: An alternative beef cattle production in Southern Nigeria. Academic Forum, 4: 36 - 40.

Ogundari, K. and Akinbogun, O. (2010).Modeling production efficiency with risk: A study of fish farms in Nigeria. Marine Resources Economics, 25 (3): 295 - 308.

Ohajianya, D.O. (2005). Econometric analysis of aggregate demand for meat in Imo State, Nigeria. Journal of Agriculture and Social Research, 5 (1): $62-66$.

Ojimba, T.P. and Odegba, Y.I. (2017). Micro level analysis of beef demand in selected parts of Rivers State, Nigeria. Science and Industrial Technology Education Journal, 5 (2): 41 53.

Osho, G.S. and Nazemzadeh, A. (2005) Consumerism: Statistical estimation of Nigeria meat demand. Journal of International Business Research, 4 (1): 1 - 7. Accessed 18/04/16. 
Premium Times Newspaper (2014). Nigeria to increase beef consumption to 1.3 milliontonnes by 2050 -Adesina. May 15, 2014.

Sadoulet, E. and de Janvry, A. (1995).Quantitative development policy analysis. Baltimore, USA, John Hopkins University Press.

SAS Institute Inc. (1999). SAS/ETS Program User's Guide,Version 8, Cary, NC: SAS Institute Inc. USA.

Saumell, C. (2014). Demand for beef in Nigeria is on the increase. Food alert. Madrid Office, Bond Bia-Irish Food Board.

Tash, M.N.S., Shabraki, J. and Jangi, S.N. (2012). Estimating the almost ideal demand system model for rural households in Iran. International Journal of Academic Research in Business and Social Sciences, 2 (8): 281 - 292.

Tey, Y.S., Shamsudin, M.N., Mohamed, Z., Abdullah, A.M. and Radam, A. (2008a). A complete demand system of food in Malaysia. ICFAI Journal of Agricultural Economics, 5 (3): $17-29$.

Tey, Y.S., Shamsudin, M.N., Mohamed, Z., Abdullah, A.M. and Radam, A. (2008b). Demand for meat products in Malaysia. www.resarchate.net, Accessed 23/02/19.

Tey, Y.S.,Shamsudin, M.N., Mohamed, Z.,Abdulah, A.M. and Radam, A. (2010). Demand analysis of meat in Malaysia. Journal of Food Product Marketing, 16 (2): 199 - 211.

Wenneberg, M., Tornevi, A.,Johansso, I.,Hornell, A.,Norberg, M. and Bergdahl, I.A.(2012).

Diet and lifestyle factors associated with fish consumption in men and women: A study of whether gender difference can result in gender specific confounding. Nutrition Journal, 11:101.doi:10.1186/1475-2891-11-101.

Yusuf, O.I.S. (2012). A system of the demand for animal protein in rural and urban Nigeria. A case study of Ibadan Metropolis. Journal of Research in National Development (JORIND), 10 (2): $208-213$. 